\title{
A histomorphological study of trichilemmal cysts: a rural hospital experience
}

\author{
Ranjan S. ${ }^{1}$, Goud H.K. ${ }^{2}$ \\ ${ }^{1}$ Dr. Siva Ranjan. D, Assistant Professor, ${ }^{2}$ Dr. G Hari Kishan Goud, Associate Professor, Department of Pathology, P.K. \\ Das Institute of Medical Sciences, Palakkad - Ponnani Road, Ottapalam, District Palakkad, Vaniamkulam, Kerala, India.
}

Corresponding Author: Dr. G. Hari Kishan Goud, Associate Professor, Department of Pathology, P.K. Das Institute of Medical Sciences Palakkad- Ponnani Road, Ottapalam, District Palakkad, Vaniamkulam, Kerala, India, Email: avis.reddy@gmail.com

\begin{abstract}
Introduction: Among Cystic lesions of skin the most common clinical diagnosis is sebaceous cyst. Cystic lesions of the skin are most commonly encountered in surgical practice. Among these cyst lesions Trichilemmal cysts are very rare and these cysts are benign non-neoplastic lesions. pilar theory says that the follicular isthmus of the external root sheath of the hair follicle as the exact origin of these pilar cysts and suggested the name "trichilemmal cyst." Objectives: The present study was undertaken to study and find out the incidence of Trichilemmal cysts in a rural area and to study the various histomorphological forms of Trichilemmal cysts which were encountered in surgical pathology in and around Konaseema region at rural hospital over a period of three years. Methods: This was a three years retrospective study done between January 2012 to December 2014, the data retrieved from histopathology files. The paraffin embedded and H\&E stained slides were removed from the files. A few old slides were re-stained again with hematoxylin and eosin, these slides studied under microscope and histomorphological features were noted. Result: Out of 135 skin lesions which were retrieved, seven cases $(5.18 \%)$ showed Trichilemmal differentiation. Out of these seven cases one case showed the features of proliferating trichilemmal cyst and other one more case showed features of malignant proliferating trichilemmal cyst. Conclusion: Extensive histomorphological examination is must for cysts showing the trichilemmal type of keratinisation, because many of these lesions may be mistakenly diagnosed as squamous cell carcinomas.
\end{abstract}

Key words: Trichilemmal cyst, Cystic lesions, Histomorphological examination.

\section{Introduction}

Trichilemmal cysts are benign non-neoplastic lesions; the related neoplastic lesions are Proliferating trichilemmal cyst/ tumor and malignant proliferating trichilemmal cyst/ tumor. Review of literature showed the following synonyms for proliferating trichilemmal cyst [1-3]. Epidermoid carcinoma in sebaceous cyst, sub epidermal acanthoma, trichochlamy docarcinoma Proliferating epidermoid cyst, Invasive hair matrix tumour of the scalp, Giant hair matrix tumour, Proliferating pilar cyst, proliferating trichilemmal cyst, proliferating trichilemmal cystic squamous cell carcinoma, proliferating isthmica cystic carcinoma and Proliferating follicular cystic neoplasm. These cysts are Occurring in $5-10 \%$ of the population. Scalp is the most common site of occurrence seen in $90 \%$ of patients and

Manuscript received: $14^{\text {th }}$ January 2018

Reviewed: $24^{\text {th }}$ January 2018

Author Corrected: $30^{\text {th }}$ January 2018

Accepted for Publication: $3^{\text {rd }}$ February 2018 second most common site is head and neck region. Pinkus, identified the follicular isthmus of the external root sheath of the hair follicle as the exact origin of these Trichilemmal cysts and suggested the name "trichilemmal cyst." [4,5] A few other studies concluded that those cysts where in keratinization occurred without keratohyaline granules, were derived from the piliary apparatus, as in the cases of the cortex of hair and nail, particularly the external root sheath and hence should be called as pilar cysts.

In $2 \%$ of cases, single or multiple foci of proliferating cells lead to proliferating tumors and they are called as proliferating trichilemmal cysts or tumors. These cysts grow rapidly and they are biologically benign but locally very aggressive. Rarely, they may transform into malignant form. Cystic lesions of the skin are most commonly encountered in surgical practice. Among these cyst lesions Trichile-mmal cysts are very rare. The 
Original Research Article

present study was undertaken to find out the incidence of Trichilemmal cysts in a rural area in and around Konaseema region at rural hospital over a period of three years and to study the various histomorphological forms of Trichilemmal cysts.

\section{Materials and Methods}

Study design and settings: This was a three years Retrospective study from a period of January 2012 to December 2014; which was undertaken to study the various Histomorphological forms of Trichilemmal cysts which were retrieved from the histopathology department at Konaseema rural Hospital and to find out the incidence of these trichilemmal cysts in and around Konaseema region.
Inclusion and Exclusion Criteria: All the cases received from department of General Surgery for histopathological examination and which were diagnosed as cystic lesions of skin were included in the study.

The paraffin embedded blocks of cystic lesions of skin were retrieved and new sections were taken from those blocks and stained with Hematoxylin and Eosin.

These Hematoxylin and Eosin stained slides were studied under microscope and again histomorphological features were noted.

From the histopathology request form the clinical details were noted.

\section{Results}

Out of 135 cystic lesions of skin which were retrieved, seven cases showed Trichilemmal differentiation. Out of these seven cases one case showed the features of proliferating trichilemmal cyst and one more case showed features of malignant proliferating trichilemmal cyst. The Figure 1 shows the distribution of trichilemmal cysts

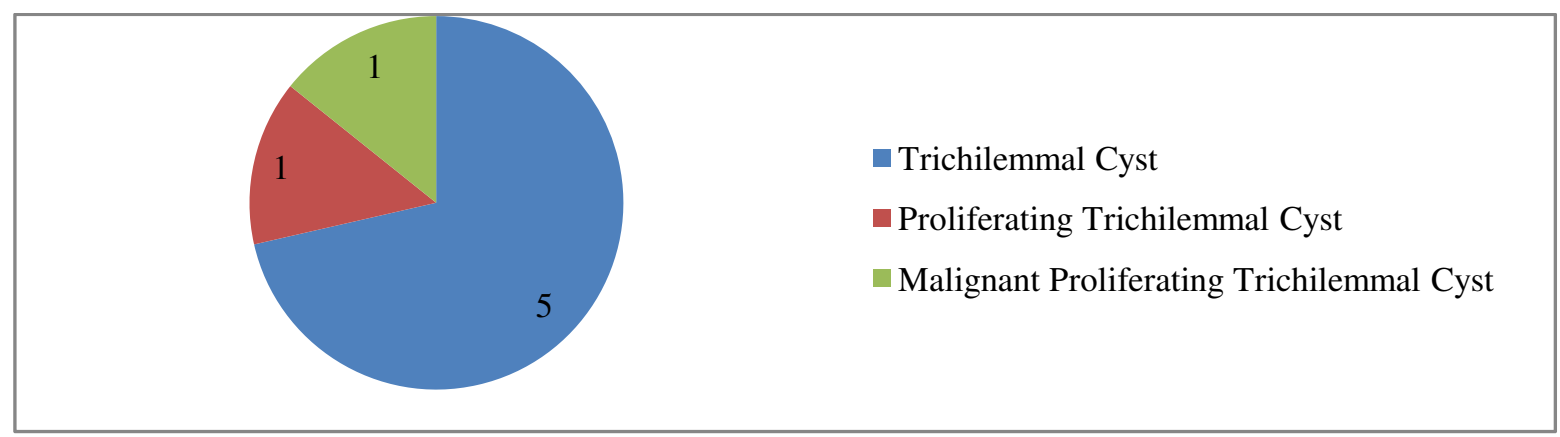

Figure-1: Distribution of trichilemmal cysts

All the seven cases of Trichilemmal differentiation were seen among females and the site of occurrence was on scalp. The age wise distributions of these cases were shown in Table 1;

Table-1: Age wise distribution of trichilemmal cysts.

\begin{tabular}{|c|c|}
\hline Age & Number of cases \\
\hline$<30$ years & 1 \\
\hline $30-40$ years & 1 \\
\hline 4050 years & 2 \\
\hline$>50$ years & 3 \\
\hline
\end{tabular}

\section{Discussion}

Trichilemmal cyst is usually a sub cutaneous lesion or solitary intradermal lesion. These are commonly found on the scalps of females [1-3]. Pinkus, identified the follicular isthmus of the external root sheath of the hair follicle as the exact origin of these Trichilemmal cysts and suggested the name "trichilemmal cyst."[4,5]. Proliferating trichilemmal cyst/tumor is a solid cystic neoplasm which is showing differentiation similar to the isthmus of the hair follicle [6,7]. Both of these trichilemmal cyst and proliferating trichilemmal tumor can occur together showing trichilemmal type of keratinization, but one is a cyst and the other one is a neoplastic proliferation. In our present study, out of 135 cases seven cases showed trichilemmal differentiation; 


\section{Original Research Article}

out of which five cases diagnosed as trichilemmal cysts, one case as proliferating trichilemmal tumor and one more case as Malignant proliferating trichilemmal tumor.

Grossly these cysts are firm in consistency with smooth walled and cut surface has single to multiple cysts cream white semi solid cheesy contents. In present study one case showed the cyst lining which was predominantly smooth with focal trabeculations and focal nodular grey white areas measuring $4 \times 3 \mathrm{~cm}$ dimension, this cyst was excised from the scalp of a 54year-old female. The cysts were filled with viscous material with the septae between adjacent lobules, multiple cysts; showing grey white nodular areas with creamy cheesy material.

Microscopic studies of these cysts are lined by stratified squamous epithelium. The cyst is filled by homogeneous eosinophilic material but in the epidermal cyst it is lamellated keratin flakes are seen. The keratinization is abrupt with no intervening granular layer. Cholesterol clefts are common [3]. All the cases in our Retrospective study showed the classical histomorphological features as stated above. The histomorphology of these tumors shows the nests of the squamous cells extending into the adjacent connective tissue, but the proliferation of these cells is mostly inwards into the cyst. These cells differentiate towards larger keratinocytes with abundant eosinophilic cytoplasm. The Remnants of trichilemmal cysts can be seen at one end [8].

Jay Ye and his co-workers study showed Seventy-six cases of proliferating trichilemmal tumors. They proposed that these tumors can be stratified into three groups based on degree of nuclear atypia, tumor silhouette, mitotic activity, perineural invasion and necrosis. Group 3 tumors having metastatic potential. Group 2 tumors have a potential for locally aggressive growth and Group 1 tumors are considered benign [9]. Surgical excision is curative for most cases of proliferating trichilemmal tumors and pursue a favorable clinical course. DNA aneuploidy and high proliferative activity indicates malignant transformation. Lymph node metastasis at the time of presentation of malignant proliferating trichilemmal tumor has been reported in literature [10,11]. In this present study one case of proliferating trichilemmal tumors and one case of Malignant proliferating trichilemmal tumor were retrieved. The clinical history of the malignant proliferating trichilemmal tumor case states that there was no metastatic lymphnode involvement. Neoplasms whose differentiation is towards one or more of the adnexal structures of the skin are Appendageal tumors. Trichilemmal cysts are usually sub cutaneous or solitary intradermal or lesions. They are clinically indistinguishable from epidermal cysts though being less common than them. These cysts are commonly found on the scalps of females. They are easily enucleable with no punctum in contrast to epidermal cysts [12-14]. In our retrospective study the clinical data revealed that most of the cases which were surgically removed were noted on the scalp of middle aged females.

A trichilemmal cyst can be seen some times in association with a proliferating trichilemmal tumor, the lesion by itself is not a neoplasm. It lacks the multilobular architecture of its neoplastic counterpart. Proliferating epidermoid or infundibular cyst is most common in males in the region of anogenital area.

Morphologically they are lined by stratified squamous epithelium with in fundibular keratinization and show a cystic cavity. Malignant proliferating trichilemmal tumor is a lesion commonly presenting as a slow growing indurated plaque, epidermal papule and nodule that may ulcerate on the face or ears. Morphologically these tumors are predominantly composed of cytologically atypical clear cells resembling that of outer root sheath. These cells have prominent cytological atypia with foci of pilar type keratinization.

In our study one case of malignant proliferating trichilemmal tumor was noted and showed the histomorphological features similarly as stated above. Malignant transformation of an epidermal inclusion cyst is uncommon which may be confused for a proliferating trichilemmal tumor and a very few cases have been reported in literature. This shows the importance of examining all cystic lesions of the skin [15]. However, some times, these cysts clinically may become tender and inflamed and when these cysts rupture, the surrounding tissue shows areas of inflammation.

Wilson Jones first described these lesions as a proliferating epidermoid cyst. Similar to trichilemmal cyst, These tumors present as large, multilobular, solitary, exophytic masses. Proliferating trichilemmal tumor has a predilection for the scalp in females where dense areas of hair follicles were seen and also on trunk, back are the other common sites [3,7]. In our study the clinical history says that all the seven cases are of scalp swelling and out of which three cases are seen in elderly women whose age is above 50 years. 


\section{Original Research Article}

\section{Conclusion}

To conclude, the cyst excised from the skin should be closely studied grossly and microscopically, mostly the larger lobulated masses. Extensive histomorphological examination is must for cysts showing the trichilemmal type of keratinisation, because many of these lesions may be mistakenly diagnosed as squamous cell carcinomas.

Funding: Nil, Conflict of interest: None initiated Permission from IRB: Yes

\section{References}

1. Kirkham N. Tumors and cysts of the epidermis. In: Elder DE, Elenitsas R, Johnson BL, Murphy GF, editors. Lever's Histopathology of the skin. 9th ed. Philadelphia: Lippincott Williams and Wilkins; 2005. pp. 814-6.

2.Rosai J. Rosai and Ackerman's surgical pathology. 9th ed. Vol. 1. St Louis: Mosby; 2004. pp. 151-3.

3.Weedon D. Skin pathology. 2nd ed. Edinburgh: Churchill Livingstone; 2002. pp. 504-7.

4. Chandrasekaran V, Parkash S, Raghuveer CV. Epidermal cysts- a clinic pathological and biochemical study. Postgrad Med J. 1980 Dec; 56 (662):823-7.

5. Warvi WN, Gates O. Epithelial Cysts and Cystic Tumors of the Skin.Am J Pathol.1943Sep;19(5):765-83.

6. Klein W, Chan E, Seykora JT. Tumors of the epidermal appendages. In: Elder DE, Elenitsas R, Johnson BL, editors. Lever's Histopathology of the Skin. 9th ed. Philadelphia: Lippincott Williams and Wilkins; 2005. pp. 882-6.

7. Kaddu S, Requena L. Malignant tumors with follicular differentiation. In: Le Boit PE, Burg G, Weedon D, Sarasin A, editors. Pathology and Genetics of Skin Tumors. Lyon: IARC press; 2006. pp. 149-51.
8. Kumar P, Chatura KR, Haravi RM, Chandra sekhar HR. Proliferating trichilemmal cyst mimicking squamous cell carcinoma. Indian J Dermatol Venereol Leprol. 2000; 66:149-50.

9. Ye J, Nappi O, Swanson PE, Patterson JW, Wick MR. Proliferating pilar tumors: a clinic pathologic study of 76 cases with a proposal for definition of benign and malignant variants. Am J Clin Pathol. 2004 Oct;122 (4): $566-74$.

10. Siddha M, Budrukkar A, Shet T, Deshpande M, Basu A, Patil N, Bhalavat R. Malignant pilar tumor of the scalp: a case report and review of literature. J Cancer Res Ther. 2007 Oct-Dec;3(4):240-3.

11. Bae SB, Lee KK, Kim JS, Lee JH, Lee NS, Lee GT, et al. A case of malignant proliferating trichilemmoma of the scalp with multiple metastases. Korean J Intern Med. 2001;16:40-3.

12. Hurt MA, Santa Cruz DJ. Tumors of the skin. In: Fletcher CD, editor. Diagnostic Histopathology of Tumors. 2nd ed. Vol. 2. London: Churchill Livings tone; 2000. pp. 1400-4.

13. Nair PS. A clinic pathologic study of skin appendageal tumors. Indian $\mathrm{J}$ Dermatol Venereol Leprol. 2008 Sep-Oct;74(5):550.

14. Buis PA, Verweij W, van Diest PJ. Value of histopathologic analysis of subcutis excisions by general practitioners. BMC Fam Pract. 2007;8:5. [PMC free article] [PubMed]

15. Ziadi S, Trimeche M, Hammedi F, Sriha B, Jomaa W, Mokni M, Korbi S. Squamous cell carcinoma arising from an epidermal inclusion cyst: A case report. N Am J Med Sci. 2010 Jan; 2(1):46-7.

\section{How to cite this article?}

Ranjan S, Goud H.K. A histomorphological study of trichilemmal cysts: a rural hospital experience. Trop J Path Micro 2018;4(1):117-120. doi: 10.17511/jopm.2018.i1.21 